Available online on 15.3.2018 at http://ujpr.org
Universal Journal of Pharmaceutical Research
An International Peer Reviewed Journal
Open access to Pharmaceutical research

\title{
THE RELATION BETWEEN GENERAL HEALTH AND ORGANIZATIONAL PERFORMANCE IN PERSONNEL OF SHIRAZ CITY EMERGENCY IN 2017 Abbas Yazdanpanah ${ }^{1}$ (D) Ali Amiri ${ }^{1}$ (D), Ali Khani Jeihooni ${ }^{2}$ iD \\ ${ }^{I}$ Department of Healthcare Management, Marvdasht Branch, Islamic Azad University, Marvdasht, Iran. ${ }^{2}$ Department of Public Health, School of Health, Fasa University of Medical Sciences, Fasa, Iran.
}

\section{ABSTRACT}

Objectives: Health is the fundamental right of every human and a social goal and all governments and organizations are bound to supply individuals' health and organizational performance is considered one of the most important structures discussed in management projects and undoubtedly the most important criterion of assessing success in commercial companies. The general objective of this study is to examine the relation between general health and organizational performance of authorities and personnel of Shiraz city emergency in 2017. This study is applied in respect of objective.

Methods: The statistical population in the present study includes all Shiraz City emergency personnel. And their number according to obtained results is 200 persons that based on the table of Cochran sample content, 125 persons were specified as research sample. In this study, two questionnaires were used. Firstly, for examining the general health, Goldberg and Hiller measurement instrument (1979) was used. Also, for examining the organizational performance, Heresy and Goldsmith questionnaire was used. For analysis of the collected data Pearson correlation coefficient test and regression were used and using SPSS software version 18 , the research hypotheses were examined.

Results: The results of the research showed that there is a significant and positive relation between general health and organizational performance of Shiraz City emergency personnel and also there is a significant and positive relation between physical symptoms, signs of social function as components of general health and organizational performance of Shiraz city emergency personnel. There is a negative relation between anxiety symptoms and depression symptoms as components of general health and organizational performance of Shiraz city emergency personnel.

Conclusion: The results of multiple correlation coefficient show that there is a direct and significant relation between components of general health and organizational performance $(r=0.499)$ and the determination factor $\mathrm{r}^{2}$ shows that $25 \%$ of organizational performance variance is related to the mentioned factors and $75 \%$ is related to factors out of model.

Therefore, training general health and organizational performance should be one of operational goals of Shiraz city emergency personnel and this should be considered in training planning.

Keywords: Emergency, general health, organizational performance.

Article Info: Received 16 December 2017; Revised 5 February; Accepted 4 March, Available online 15 March 2018

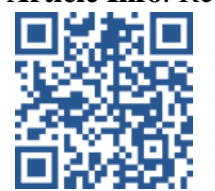

\section{Cite this article-}

Yazdanpanah A, Amiri A, Jeihooni AK. The relation between general health and organizational performance in personnel of Shiraz city emergency in 2017. Universal Journal of Pharmaceutical Research 2018; 3(1): 25-29.

DOI: http://doi.org/10.22270/ujpr.v3i1.R5

Address for Correspondence:

Abbas Yazdanpanah, Department of Healthcare Management, Marvdasht Branch, Islamic Azad University, Marvdasht, Iran. E-mail: abbas_yaz@miau.ac.ir

\section{INTRODUCTION}

Organizational performance is one of the most important structures in management projects and undoubtedly is considered success assessment criterion in commercial companies ${ }^{1}$. Generally, organizational performance indicators are divided to two categories of objective and subjective. The objective indicators of organizational performance are indicators which are measured quite real and based on objective data ${ }^{2,3,4}$. Among objective indicators of organizational performance, we can point to profitability indicators like return on asset, return on equity, return on investment and dividend and stock return. Subjective indicators of organizational performance more includes indicators which are formed based on judgment of the organization stakeholder groups. Among these indicators, we can point to customers' satisfaction, personnel satisfaction, success in providing new products and other cases ${ }^{1}$. The organizational performance is the result of administrative processes and realization of the organization objectives. In another definition, the organizational performance includes putting through the duties which are undertaken by human forces ${ }^{2}$. The organizational 
performance almost includes all objectives of competitiveness and production ascendancy and is related to cost, flexibility, speed, trustiness or quality. Moreover, the organizational performance could be defined as an umbrella which includes all concepts related to success and the whole organization activities. The organizations with superior performance have special features in respect of perspective and the organization missions, objectives, strategic reflection, leadership, the organization design, technology and organizational processes ${ }^{5-7}$. In an organization with superior performance, main drivers of performance are determined by mission statement. One of the most important and fundamental features of an organization with superior performance is its perspective and mission and the organizations with superior performance explain clear and measurable objectives ${ }^{3}$. One of components of a successful manager is his general health ${ }^{8,9}$. Generally in the organization definition health is considered as complete goodness in respect of world health, physical, mental and social health is an issue which has designated many studies to itself, so that the conducted studies in recent years clearly show a close relation between general health and personality and psychological factors ${ }^{3}$. The World Health Organization definition indicates that health is a multidimensional subject and it should be noticed that various dimensions of health and or illness influence each other and are impacted by each other. So the performed measurements for health promotion should notice all individual health aspects (physical, mental and social). The most usual dimension of health is physical health which could be simply evaluated in comparison with other dimensions. In biological respect, suitable function of cells and body organs and their coordination with each other shows physical health ${ }^{4}$. On the other hand, World Health Organization in 2004 defines mental health as a state of healthy life in which the empowered individual knows himself and uses them effectively and productively and is useful for his society ${ }^{10,11}$. It is obvious that assessing mental health is more difficult than physical health. In this definition, only lack of mental health is not considered. But accommodation and consistence with environmental conditions is to have suitable reaction and judgment against life problems and events and having the spirit of competiveness constitutes an important aspect of mental health. It should be mentioned that many mental diseases like depression, anxiety and so on influence physical health and there is a mutual relation between mental and physical diseases ${ }^{5}$. Moreover, management and leadership have been noticed by scholars as one of fundamental factors in realizing the organizational objectives. Though, the organizations are encountered with complexities and challenges inside and outside the organization, but the organizations success mostly depends on the managers' success in directing and leading the personnel and this requires the manager to have physical, mental and social health $^{12,13}$. Managers, who enjoy general health, could communicate more effectively with their subordinates, handle the requirements of organizational life and create a suitable atmosphere for work and activity in the organization ${ }^{6}$. In the working life of managers, what is more tangible is great working pressure and time and resources shortage. If great pressure is imposed on the manager for a long time, his energy is consumed, uncertainty and anxiety are developed which leads to his spiritual concern and spiritual concern sometimes leads to chronic diseases and even death ${ }^{7}$. Based the issues stated, this study seeks to answer this main question that what are the variables of general health which could increase the organizational performance in Shiraz city emergency personnel? Is there a significant relation between general health and organizational performance in Shiraz city emergency personnel?

\section{METHODS}

The method of the present study is descriptive and of survey type and the statistical population in the present study includes all Shiraz city personnel and authorities. And according to the obtained statistics, their number is 200 people. And for determining the sample content, sample determination table known as determinate society (Cochran table) was used. Regarding the Cochran table for a population equal to 200 people, the number of sample was considered 125 and it was distributed by simple random method between the people. For collecting the considered data, 2 standard questionnaire of Goldberg general heath (GHQ) and the standard questionnaire of Hersi and Goldsmith organizational performance have been for investigating the general health and organizational performance of Shiraz city personnel and authorities ${ }^{14,15,16}$. The questionnaires were adjusted based on 5-value scale and includes 5 ranges (very low, low, medium, high and very high) that scores $1,2,3,4,5$ respectively designated from very low to very high. Validity indicator, items of assessment instrument has been of superficial validity of experts consensus and the validity of the questionnaire was confirmed by means of exploratory factor analysis and reliability of the questionnaire has been obtained using Cranach's Coefficient Alpha that reliability coefficient for GHQ was obtained 0.91 and for the standard questionnaire of Hersi and Goldsmith organizational performance 0.82. The obtained results have been expressed using SPSS software and in two descriptive and illative levels ${ }^{17,18,19}$.

\section{RESULTS}

For using parametric tests for investigating the research hypotheses, the assumption of normality of variables was confirmed using Kolmogorov Smirnov method (by observing Table 1 and examining significance all subscales are greater than 0.05$)^{\mathbf{2 0 , 2 1}}$.

As it is observed in Table 2, regarding the correlation coefficient and significance level $(p=0.21, \mathrm{r}=0.001)$, there is a significant relation between general health and organizational performance of Shiraz city emergency personnel. Regarding the correlation coefficient and significance level $(p=0.28, \mathrm{r}=0.001)$, there is a significant and positive relation between components of general health and organizational performance of Shiraz city emergency personnel. 
Table 1: The results of normality of variables.

\begin{tabular}{|c|c|c|c|c|c|}
\hline \multirow[t]{2}{*}{ Particular } & \multirow{2}{*}{$\begin{array}{l}\text { Organizational } \\
\text { performance }\end{array}$} & \multicolumn{4}{|c|}{ Subscales of general health } \\
\hline & & $\begin{array}{c}\text { Physical } \\
\text { symptoms }\end{array}$ & $\begin{array}{l}\text { Anxiety } \\
\text { symptoms }\end{array}$ & $\begin{array}{l}\text { Depression } \\
\text { symptoms }\end{array}$ & $\begin{array}{c}\text { Social functions } \\
\text { signs }\end{array}$ \\
\hline Number & 125 & 125 & 125 & 125 & 125 \\
\hline $\begin{array}{l}\text { Kolmogorov- } \\
\text { Smirnov }\end{array}$ & 0.62 & 0.81 & 0.83 & 0.76 & 0.61 \\
\hline $\begin{array}{l}\text { Significance } \\
\text { level }\end{array}$ & 0.17 & 0.19 & 0.25 & 0.23 & 0.31 \\
\hline
\end{tabular}

Table 2: The results of Pearson correlation test.

\begin{tabular}{ccc}
\hline $\begin{array}{c}\text { Significance } \\
\text { level } \\
(\mathbf{P})\end{array}$ & $\begin{array}{c}\text { Pearson } \\
\text { Correlation } \\
\text { coefficient } \\
(\mathbf{r})\end{array}$ & Statistical indicators and variable \\
\hline${ }^{*} 0.001$ & 0.21 & Between general health and organizational performance \\
\hline $0.001 *$ & 0.28 & $\begin{array}{c}\text { Between physical symptoms as a component of general } \\
\text { health and organizational performance of Shiraz city } \\
\text { emergency personnel }\end{array}$ \\
\hline $0.028 *$ & -0.19 & $\begin{array}{c}\text { Between anxiety symptoms as a component of general } \\
\text { health and organizational performance of Shiraz city } \\
\text { emergency personnel }\end{array}$ \\
\hline$* 0.001$ & $0.18-$ & $\begin{array}{c}\text { Between depression symptoms as a component of general } \\
\text { health and organizational performance of Shiraz city } \\
\text { emergency personnel }\end{array}$ \\
\hline $0.001 *$ & 0.34 & $\begin{array}{c}\text { Between factors of social function as a component of } \\
\text { general health and organizational performance of Shiraz } \\
\text { city emergency personnel }\end{array}$ \\
\hline
\end{tabular}

Regarding the correlation coefficient and significance level ( $p=-0.18, \mathrm{r}=0.001)$, there is a significant and negative relation between components of general health and organizational performance of Shiraz city emergency personnel. Regarding the correlation coefficient and significance level $(p=0.34, \mathrm{r}=0.001)$, there is a significant and positive relation between social function signs as a components of general health and organizational performance of Shiraz city emergency personnel. The results of multiple correlation coefficient (Table 3) shows that there is a direct and significant relation between general health and organizational performance $(\mathrm{r}=0.499)$ and $\mathrm{r}^{2}$ determination coefficient shows that $25 \%$ of organizational performance variance is related to the mentioned factors and 75 is related to factors out of model. The results of multivariate regression (4) show that components of general health are qualified of predicting organizational performance. The results relating to regression inclination about predicting variables show that there is a direct relation between components of general health. Beta coefficient shows that they are the most important factors predicting organizational performance.

\section{DISCUSSION}

The results showed that there is a significant and positive relation between general health and performance evaluation. Health is more considered as an instrument for achieving an objective that could be stated in functional respect as a resource, a source that allows the individuals to have a suitable economic and social life. Health is not only living but it is a source for daily life. Health is a positive concept which emphasizes social and personal resources and facilities and also physical abilities ${ }^{8}$. According to a study the information obtained from performance measurement are widely used for service compensation, performance improvement and documentation". Also, it could be used in decisions relating to personnel (such as promotion, transfer, dismiss and discharge from service), analysis of training needs, personnel development, program research and evaluation. In a study it was enumerated the objectives of personnel in personnel development, creating motivation, human power planning and employment and creating the effective relations between personnel and directors ${ }^{\mathbf{1 0}}$. This hypothesis is consistent with the following studies: Maghami et al., in their study under the title of the impact of job satisfaction, performance and personnel mental health, concluded that there is a significant and positive relation between mental health and personnel performance ${ }^{10}$.

Table 3: The multiple correlation results between dimensions of general health and organizational performance.

\begin{tabular}{ccccc}
\hline $\mathbf{P}$ & $\mathbf{R}^{2}$ & $\mathbf{r}$ & $\mathbf{n}$ & $\begin{array}{c}\text { Regression } \\
\text { model }\end{array}$ \\
\hline 0.001 & 0.25 & 0.499 & 125 & ---- \\
\hline
\end{tabular}

Vosoughi et al., in their study, under the title of investigating the job stress impact on general health and personnel performance concluded that there is a significant and positive relation between general health and personnel performance ${ }^{11}$. Also, Maghsoodi et al., findings showed that there is a significant and positive relation between general health components and performance evaluation. 
Table 4: Regression equation of predicting variable of general health and organizational performance.

\begin{tabular}{cccccccc}
\hline \multicolumn{2}{c}{$\begin{array}{c}\text { Correlation } \\
\text { coefficient }\end{array}$} & $\mathbf{p}$ & $\mathbf{t}$ & $\begin{array}{c}\text { Criterion } \\
\text { coefficient }\end{array}$ & \multicolumn{2}{c}{$\begin{array}{c}\text { Non-criterion } \\
\text { coefficient }\end{array}$} & $\begin{array}{c}\text { Step by step } \\
\text { regression }\end{array}$ \\
\hline Ration & $\begin{array}{c}\text { Rank } \\
\text { zero }\end{array}$ & & & Beta & Sd. er & $\mathbf{B}$ & \\
\hline & & 0.000 & 14.582 & & 0126 & 1.834 & $\begin{array}{c}\text { Width from origin a } \\
\text { General health }\end{array}$ \\
\hline 0.110 & 0.292 & 0.107 & 1.620 & 0.111 & 0.037 & 0.060 & Physical symptoms \\
\hline 0.172 & 0.343 & 0.110 & 2.566 & 0.173 & 0.041 & 0.140 & Anxiety symptoms \\
\hline 0.159 & 0.413 & 0.019 & 2.357 & 0.186 & 0.043 & 0.101 & Depression \\
\hline 0.46 & 0.186 & 0.505 & 0.688 & 0.042 & 0.032 & 0.021 & symptoms \\
\hline 0.155 & 0.411 & 0.411 & 2.320 & 0.177 & 0.037 & 0.084 & Social function signs \\
\hline
\end{tabular}

The results showed that there is a positive and significant relation between physical signs and organizational performance. Physical health focuses on this dimension of health relating to body organs function. Physical health is a state where all body functions are performed correctly. Possibly, the physical dimension of health could be comprehended easier than other dimensions. Physical health indicates the body full function which considers biological health as the optimal state of function of every cell or body organ and with full coordination with other organs. Yet, this optimal word has not been correctly defined. Maghami et al., in their study under the title of the impact of job satisfaction on personnel performance and mental health concluded that there is a positive and significant relation between physical health and personnel performance ${ }^{13}$. Bogler et al., in their study concluded that one of ways of increasing performance is physical health and enjoying suitable appearance ${ }^{21}$. The results showed that there is a significant and negative relation between anxiety symptoms and organizational performance. Imani et al., in their study found out that special mental problems has a negative relation with personnel performance and it seems that risky working environments has a negative relation with losing mental health and cause anxiety ${ }^{19}$. Also, we concluded that by increasing of anxiety personnel performance is lowered and by increasing anxiety performance increases. The results showed that there is a negative and significant relation between depression symptoms and organizational performance. Depression is a deprivation and failure in achieving a human goals and it has some features like reduction of social communications and frustration. Reduction of anxiety has been one of the most important dimensions of development and improvement of human resources. The studies in recent decades have shown that depression factors have been growing among personnel in the organizations. The results showed that there is a reverse and significant relation between anxiety symptoms and organizational performance. Khazaei et al., in a study under the title of the relation of depression and self-respect with academic achievement of Birj and students in 2012 concluded that there is a reverse relation between depression and students' progress and performance and the less depression, the students show better progress and academic performance which is consistent with findings of this study ${ }^{19}$. McCarty et al., studies showed that the more is depression, the weaker is the students' academic performance which is consistent with findings of this study $^{20}$. Imani et al., in their study, found out that special mental problems of working environments have a negative relation with personnel performance. And it seems that risky working environments have a negative relation with losing mental health and anxiety ${ }^{22}$. Also, we concluded that by increasing of depression, personnel performance is lowered and by reducing depression, performance increases.

Health social dimension includes social skills, social performance and the ability of self-recognizing each person as a member of a bigger society. Likook defines social health as the individuals' conditions and welfare in social relations network including family, society and nation. Dnald in 1979 has provided an important and useful definition of social health: social health means quality and quantity of involving persons with the society ${ }^{23}$. Larson defines social health as the individual report of his relations quality with other people (relatives and social groups) of which he is a member and believes that social health scale evaluates a part of the individual health and includes the individual internal responses 9 feeling, thought and behavior) which indicates satisfaction or nonsatisfaction of the individual with his life and social environment. Larson expresses that key of decision making is that a part of social health is a part of the individual health and his non-satisfaction with his society has been shown. Social health which has been discussed by Ryff considers the concept of social health including mental positive performance that these dimensions include: self-acceptance, dominance on the environment, having goals in life and independence. Kiz proposed the dimension of social health under the influence of health that is usable in individual levels. Ghorbani et al., in a study under the title of effectiveness of training social functions on students' skills concluded that social functions increase the students' social skills and they have a significant and positive relation with each other and this is consistent with the findings of this study ${ }^{24}$. The results of multiple correlation coefficient show that there is a direct and significant relation between general health and organizational performance $(\mathrm{r}=0.499)$ and the determination coefficient $r^{2}$ shows that $25 \%$ of variance of organizational performance and 75 is related to factors out of model. Bernardin et al., believes that information obtained from performance measurement is widely used for service compensation, performance improvement and documentation ${ }^{17}$. Also, it could be 
used in decisions relating to personnel (such as promotion, transfer, dismiss and discharge from service), analysis of training needs, personnel development and plan evaluation and research. Ivancevich et al., has considered the aims of evaluating personnel as personnel development, human power planning and employment and creating effective relation between personnel and directors ${ }^{25}$.

\section{CONCLUSION}

This hypothesis is consistent with the following studies: Maghami et al., in their study under the title of the impact of job satisfaction, performance and personnel mental health, concluded that there is a significant and positive relation between mental health and personnel performance ${ }^{21}$. Vosoughi et al., in their study, under the title of investigating the job stress impact on general health and personnel performance concluded that there is a significant and positive relation between general health and personnel performance. Also, Maghsoodi et al., in their study showed that there is a significant and positive relation between general health components and performance evaluation $^{16}$. The present study findings are consistent with studies of Bigdeli et al., Bogler et al., and Sheikh et al. ${ }^{5,8,12,17}$

\section{AUTHOR'S CONTRIBUTION}

The manuscript was carried out, written, and approved in collaboration with all authors.

\section{ACKNOWLEDGEMENTS}

The authors extend their thanks and appreciation to the Islamic Azad University, Marvdasht, Iran to provide necessary facilities for this work.

\section{CONFLICT OF INTEREST}

No conflict of interest associated with this work.

\section{REFERENCES}

1. Parhizgar K. Human relations in organizational management 2011; 322.

2. Mahmoud S. Efficiency psychology (labor psychology applied dimensions and industrial and organizational psychology), Tehran, Nashr Virayesh Institute 2003; 2-6

3. Salehi L. The relation between religious beliefs and control resource with mental health in students, scientific J Gazvin University of Medical Sciences, $11^{\text {th }}$ year 2007; 1: 50-65 https://doi.org/10.4103/0019-5545.105526

4. Hashemi N, Saeid S. Investigating mental health of Tehran firefighting personnel, Hakim research J. 2007; $10^{\text {th }}$ period, 2. https://doi.org/10.4103/jfmpc.jfmpc_16_19

5. Seyed H, A Foroozan, Setareh Amir, Faryar, Masoumeh. Mental health of women custodian of family under coverage of welfare organization, social research journal, $2^{\text {nd }}$ year. $2009 ; 3$

6. Ferdosi, Hassan M, Marashian, Fatemeh, Talebpour Mehdi. The relation between personality features and organizational commitment with organizational health in general office of youths and sport of Khozestan province, sport management studies 2012; 15: 173-188.
7. Hajian A, Ali Mohammad A, Masoud M. The performance evaluation model in non-industrial research organizations, $\mathrm{J}$ human resources management research of Imam Hossein University, $5^{\text {th }}$ year 2013; 2: 81-105.

8. Mohammad H, Ebrahim G, Samaneh M, Nikbakht F. Investigating the relation between features of the organization mission statement and organizational performance (case study in Tehran food stuff active companies). Evol Manag Res J 2010; 2(4): 175.

9. Roghani A, Mehdi A, Soltani I. Identifying key indicators of individuals performance evaluation for reward payment, process and development journal, period 2012; 25(3): 81 .

10. Noupasand A, Malek S, Esmaeil A, Hosseini A, Mahrovani M. J human resources management research Imam Hossein University $2013 ; 6(1): 31-51$.

https://doi.org/10.22037/bj.v9i0.26919

11. Bagheri M, Tavalaei R. Investigating organizational commitment on organizations performance, scientific journal of Police human power development 2013; 31. https://doi.org/10.6007/IJAREMS/v2-i5/299

12. Allen RS, Dawson G, Wheatley K. Diversity Perceive White, C.S. Performance. Employee Relations 2008; 30(1): 20. https://doi.org/10.1108/01425450810835392

13. Amaratunga D, Baldry D. Moving from performance measurement to performance management, Facilities. 2002; 20: (5/6), 21. https://doi.org/10.1108/02632770210426701

14. Hiltrop JM. The Quest for the Best, Europ Manag J. 1999; 17(4): 422

15. Mishara Gayatra, Parvasn Kumar, Patan Yac. The multi menials natural of organizational commitment $\mathrm{J}$ safety vs. earch. 2009; 25, 42-59.

16. Mosher, Catherine E, Sharon Danoff-Burg. Indoor tanning, mental health, and substance use among college students: the significance of gender. J Health Psychol 2010; 2(1), 1-9. https://doi.org/10.1177/1359105309357091

17. Nelarine C, Larraine G. Performance management: strategy, systems and rewards; Thomson Learning, London, 2009.

18. Kartalova Yulia-O’Doherty, Donna Tedstone Doherty. Recovering from mental health problems: Perceived positive and negative effects of medication on reconnecting with life. Int J Social Psychiatry 2010; 2(1): 1-9. https://doi.org/10.1177/0020764010377396

19. Kumar S, Tiwari PC, Isnara MM. Work steers and health as-predictorcs of organization commitment. J Sufly Res $2008 ; 25,42-59$.

20. Robret T, Jennifer HG. Identifying acceptable performance appraisal criteria: an international perspective. Asia pacific J Human recourse. 2009; 17 (1): 102-125. https://doi.org/10.1177/1038411108099292

21. Tortosa V, Moliner MA, Sa'nchez J. Internal Market Orientation and Its influence on organizational performance. Europ J Market 2009; 43(11:12): 1435-1456. https://doi.org/10.1108/03090560910989975

22. Turkoz I, Akyol A. Internal marketing and hotel performance. Anatolia: An Int J Tourism Hospitality Res 2008; 19(1): 177-149. https://doi.org/10.1080/13032917.2008.9687059

23. Turner RJ, Lioyd DA. The sties process and Social distribution of depression. J health social behavior. 1999; 40, 371-404. PMID: 10643162

24. William Li, Ho Cheung, Siu Long Polly Chan, Oi Kwan Joyce Chung. Relationships among Mental Health, Selfesteem and Physical Health in Chinese Adolescents, An Exploratory Study. J Health Psychology 2010; 15: 1. https://doi.org/10.1177\%2F1359105309342601

25. Ybrandt H, Kerstin A. Peer aggression and mental health problems, Self-esteem as a mediator, school psychology International 2010; 31(2): 146-163. https://doi.org/10.1177\%2F0143034309352267 